\title{
Resenhas
}

\section{Dificuldades de Leitura}

Fink, Rosalie (2006). Why Jane and John couldn't read and how they learned: a new look at striving readers. Newark: IRA, xvi+ I75p.

Rosalie Fink é doutora em Educação pela Harvard Graduate School of Education, trabalha há anos com leitura tanto com crianças como com adultos ( dos 3 aos 55 anos). Desenvolveu um Modelo de Leitura Baseado no Interesse (IBMR) ao qual vem dedicando sua atenção. Apresenta parte dos resultados de seu empenho no presente livro o qual é de grande valia para quantos trabalham com leitura, particularmente com crianças com problemas na área.

O prefácio é escrito pela própria autora a qual lembra que na obra descreve implicações importantes do IBMR para ajudar alunos sem e com problemas, de todos os níveis de competência e de idade. Do modelo destaca os componentes: (a) interesse pessoal, apaixonado que assegura e mantem a leitura; (b) leitura ávida de tópicos específicos; (c) profundo esquema de conhecimento; (d) estratégias contextuais de leitura e (e) apoio monitorado. A obra é destinada a professores, familiares, especialistas em leitura, tutores e monitores que se envolvem com estudantes de todas as idades. O livro se apóia em 66 estudos de caso analisados pelo IBMR. Espera que seus leitores capacitem-se a usar este modelo inovador. Fecha o prefácio com vários agradecimentos.

O primeiro capítulo descreve êxito na leitura conseguido após muita luta por muitas pessoas que aparecem arroladas em um quadro que indica suas profissões e locais de trabalho. Em comum tiveram apenas o imenso esforço para conseguirem se tornar bons leitores e o fato de terem tido êxito em suas profissões as quais requerem muita leitura. Todos lutaram para aprender a ler. Com base no estudo destes casos é que foi desenvolvido o IBMR para possibilitar aos que apresentam dificuldades se tornarem leitores competentes. Complementa 0 capítulo uma lista de livros, revistas e jornais, de interesse para crianças e adultos, bem como outros recursos.

O segundo capítulo enfoca os leitores bilíngües e como podem superar suas dificuldades para ler e escrever em uma outra língua. Destaca o papel dos mentores, da família e do orgulho cultura, que podem gerar interesse pela leitura e prazer ao realizar esta atividade. Parte de exemplos de seus estudos de caso. Orientações gerais são oferecidas para as famílias e para os professores de modo que possam trabalhar melhor os interesses dos alunos e assim ajudar as pessoas a aprenderem. As artes são uma boa alavanca. O capítulo apresenta no final materiais que podem ser usados como recursos complementares.

Considerando que as pessoas podem demonstrar competências fortes em uma matéria e serem extremamente fracas em outras, que há o que se chama inteligências múltiplas isto não pode ser ignorado no ensino-aprendizagem da leitura. É o tema do $3^{\circ}$ capítulo. Crianças aprendem a ler de formas diferentes não se podendo esperar que haja um padrão único. Cabe aos responsáveis pela formação de leitores despertar as capacidades dos últimos usando textos de áreas de interesse específicos, dando apoio sociocultural, desenvolvendo esquemas, criando condições de autoconfiança, ensinando estratégias diversificadas etc. Várias sugestões são feitas destacando que o êxito em leitura tem muitos 
caminhos. Não é novidade já que há muito a literatura sobre a matéria vem demonstrando isto, tanto que há bem mais do que 250 modelos ou formas de se fazer isto. Mas Fink em seu modelo apresenta uma associação básica com os interesses do educando. No final do capítulo aparece uma série de indicações de recursos úteis especialmente para se trabalhar com os que apresentam dificuldades mas gostam de ciências.

No capítulo 4 a autora enfoca alguns mitos envolvendo a relação gênero-leitura. Considera que por volta dos 2 ou 3 anos as crianças já conhecem muitos dos estereótipos sociais sobre gênero e já procuram se comportar de acordo com eles como meio de buscar sua identidade. Esse fato pode estar na base de muitos mitos da área. $A$ autora recorre aos seus estudos de caso para tratar a matéria. As escolhas masculinas e femininas são diferentes no momento de seleção de textos, mas respeitados os seus interesses, ambos se envolvem e vivenciam igualmente o prazer da leitura, tendo a mesma empatia com personagens dos textos. As meninas tendem a ser mais estimuladas que os meninos na escola. Todavia, eles tem mais apoio no lar do que elas. As expectativas deles é de que teriam menos problemas com a leitura se fossem mulheres. A delas é que teriam mais problemas se tivessem nascido com o outro gênero. As famílias e os professores podem ajudar a superar as concepções equivocadas. São feitas algumas sugestões: leitura crítica, textos gêmeos, respeito às diferenças de interesse e de perspectivas. Novamente, no final do capítulo o leitor encontra sugestões de textos de temas diversos como o racismo, a heterossexualidade e o sexismo. Agrega ainda lista de livros sobre o ensino da escrita e obras de poesia para ambos os gêneros.

O capítulo seguinte trata de como os professores podem identificar, o mais cedo possível, quais os alunos de risco ou que terão de lutar muito para aprender a ler. Quando mais cedo receberem ajuda melhor para prevenir um fracasso no domínio da referida competência. Aparecem sempre na literatura como preditores de desempenho: o conhecimento que a criança tem das habilidades iniciais da alfabetização e velocidade para memorizar nomes de letras e o comportamento na escola. São sempre auxílio na identificação de tais crianças: se prestam a devida atenção ao ouvir uma história, se ficam atentas durante as atividades de leitura, de escrita e se estão freqüentemente "por fora" ou se são "palhaços" da classe. Outros indícios também são freqüentes embora não o sejam sempre. Entre os últimos vale lembrar problemas de pronúncia, pouco conhecimento do alfabeto, dificuldades para discriminar letras, história de dificuldades para leitura na família etc. É um capítulo muito útil para pesquisadores e para os que atuam na alfabetização.

O último capítulo é breve e tem por título Conclusões e Implicações. São retomadas as características básicas do modelo, lembrada a importância da família e que há muitos caminhos para aprender a ler e escrever. A "velocidade e fluência na leitura são altamente sensíveis e variam com a área de conteúdo, o tópico e o gênero" (p. I38). Há necessidade de se rever o conceito de fluência na leitura. Os mentores são importantes na formação de leitores, há necessidade de políticas educacionais flexíveis que encorajem os professores a recorrer a materiais que espelhem a cultura de origem dos estudantes, a desenvolver práticas e estratégias diversificadas de ensino. A principal conclusão é a de que as pessoas com dificuldades podem ter êxito.

Como apêndice o leitor encontra uma síntese da pesquisa, seu referencial teórico conceitual; uma breve revisão de trabalhos realizados com alunos que lutaram para aprender a ler; como foram conceituados, identificados e selecionados os casos estudados; o auto relato dos participantes quanto aos problemas que tiveram e outras variáveis que viabilizaram vencer as dificuldades e a terem êxito na vida adulta. Apresenta o roteiro de entrevista que aproveitou de pesquisa anterior (1995/1996) com disléxicos, quando ainda trabalhava no modelo construtivista mas já modificando-o para elaboração de seu próprio modelo, muito mais inclusivo e amplo.

As referências embora incluam clássicos como trabalho de Dewey de 1913, são predominantemente dos últimos anos do século passado e dos últimos anos (2000 em diante). No que diz respeito ao tipo de suporte predominam os livros (57\%), ficando os 
demais, mais esperados pelas regras cientométricas em segundo lugar (artigos de periódicos 30\%); textos apresentados em eventos/anais (12\%) e teses com 1\%). A distribuição possivelmente decorreu da opção de narrativa assumida por Fink. Embora apresente análise mista (quantitativa e qualitativa) de seus dados, tornou o texto mais acessível com ênfase nos aspectos qualitativos e descritivos, mais do que nos inferenciais, o que é plausível em um livro.

O leitor pode aproveitar muito com a leitura da obra pela perspectiva diferenciada que oferece, pelas sugestões implícitas e explícitas para ação e para a pesquisa. Certamente uma réplica de seu trabalho no Brasil seria útil para se conhecer melhor a aquisição e a manutenção da leitura. Também seria relevante testar cientificamente em sala de aula, em estudos experimentais bem conduzidos, as propostas do IBMR

\section{Geraldina Porto Witter Academia Paulista de Psicologia}

